Kowasch M., S.P.J. Batterbury, M. Neumann. 2015. Contested sites, land claims and economic development in Poum, New Caledonia. Settler Colonial Studies 5(4): 302-316.

\title{
Contested sites, land claims and economic development in Poum, New
} Caledonia

\author{
Matthias Kowasch ${ }^{\mathrm{a} *}$, Simon Batterbury ${ }^{\mathrm{b}}$ and Martin Neumann ${ }^{\mathrm{c}}$ \\ a Lecturer, Institute of Geography, University of Bremen, Germany \\ kowasch@uni-bremen.de \\ b Associate Professor, School of Geography, University of Melbourne, Australia \\ c Student, Raboud University, Nijmegen, Netherlands \\ *corresponding author, kowasch@uni-bremen.de
}

\begin{abstract}
Property relations are often ambiguous in postcolonial settings. Property is only considered as such if socially legitimate institutions sanction it. In indigenous communities, access to natural resources is frequently multidimensional and overlapping, subject to conflict and negotiation in a 'social arena'. Settler arrivals and new economic possibilities challenge these norms and extend the arena. The article analyses conflicts and negotiations in the French overseas territory of New Caledonia in the light of its unique settler history and economic activity, focussing on the little-studied remote northern district of Poum on the Caledonian main island Grande Terre. In this region the descendants of British fishermen intermarried with the majority Kanak clans. We illustrate the interaction between customary conflicts, European settlement, struggles for independence, and a desire for economic development. Customary claims are in tension with the attractions of economic growth and service delivery, which has been slow in coming to Poum for reasons largely outside the control of local people.
\end{abstract}

Keywords: Land claims, land conflicts, social identity, property, social arena, postcolonial settings, New Caledonia, mining development, economic benefits 


\section{Introduction}

In postcolonial settings, land and water are only considered as 'property' if socially legitimate institutions sanction this status. ${ }^{1}$ Settlers and settler-colonial states generally believed that legally obtained and individually registered property was legally defensible. But indigenous societies have maintained multidimensional and overlapping property relations that are constantly negotiated, and that sit alongside and partially overlap with Western tenure systems. This article explores the social arena and territorial disputes in the district of Poum in the far north of New Caledonia's main island 'Grande Terre'. We show how local and external agents have driven a history of conflict over land and water, linked to an absence of economic development possibilities. We first describe the social and economic history of the region, including customary relations of power and control. We then explore a particular postcolonial condition affecting the region; dashed hopes of economic development following the failure to secure a major mining initiative due to geopolitical negotiations that took place far removed from the locality. ${ }^{2}$

Our starting point is the social 'arena', a term that encompasses different definitions and forms of power. ${ }^{3}$ In an 'arena', heterogeneous strategic groups confront each other, driven by their clashing interests. In settler-colonial regimes, as LeFevre states, everyday life always '...takes place in a terrain already partly sedimented and partly penetrated by relations of power' ${ }^{4}$ Colonial settlement in the francophone Pacific disturbed the social arena through displacement of local populations, leading to territorial disputes, and resulting in significant cultural change.

In New Caledonia, the colonial period is still visible in the spatial distribution of indigenous Kanak peoples (the first Melanesian inhabitants of the islands) and non-Kanak; in effect, a duality of life spaces, culture and territory prevails. ${ }^{5}$ There is constrained intercultural communication between these two main populations, with limited fluidity in identities and cultural practices. ${ }^{6}$ In northern Grande Terre, mineral riches and the history of settlement have worked together to create a social arena marked by dissent, largely over land and water, with its origins in traditional society but magnified by the political economy of mining. ${ }^{7}$ Another concern of the article is more practical; to show how local people can deploy power to manage natural resources and through asserting social claims to property and territory, achieving livelihoods and development for their communities.

\section{Geographical and politico-economic context}

New Caledonia was settled by Austronesian peoples over 3,000 years ago, and it has been a French overseas territory since 1853 . It served as a penal colony for fifty years, housing 4,000 prisoners from the Paris Commune after 1871 and later housing prisoners from the Algerian war. ${ }^{8}$ Prisoners received a commuted sentence if they settled on the islands as libérés. Treatment of indigenous populations, displaced to make way for urban development, ranching and later mining, was harsh and culminated with the imposition of indigénat legal codes in 1887, significantly curtailing Kanak rights as sujets français (French subjects) rather than citoyens (citizens) and coercing many of them onto reserves away from their homelands and with limited freedom of movement. ${ }^{9}$ The régime de l'Indigénat was not repealed until 1946. Kanak peoples and more recent settlers from Europe, Asia and the Pacific exist today in a political condition of 'shared sovereignty', ratified in 1998 as the Nouméa Accord. Agreement on this status was provoked by violent struggles called les événements, indigenous uprisings that took place against the French colonial regime in the 1980s (major revolts also occurred in 1878 and 1917). Under shared sovereignty, France has since transferred political competences over environmental law, exploitation of resources, primary school education, etc. to a New Caledonian government, or to provincial authorities, but it has retained sovereign rights over foreign policy, defence, the currency, the courts and police; New Caledonians remain French citizens. ${ }^{10}$

New Caledonia, unlike other Pacific nations, has an extensive, multi-billion dollar nickel mining industry that dwarfs other sources of state and private revenue. Historically, mining-related economic development was sanctioned only by the state. This situation changed with the Nouméa Accord, which mandated changes in governance and the establishment of provincial authorities that largely mirrored existing ethnic divisions and were empowered with budgets and new powers. ${ }^{11}$ Northern Grande Terre became the Northern Province, under Kanak majority control. A development of 
particular note was the Province's initiation of a large nickel mine and smelter, at the Koniambo massif, in 2008. Production commenced in 2014. The government of the Northern Province supports independence from France, and has encouraged urban development and job creation in the neighbourhood of the new nickel smelter, that it controls through its mining company SMSP (Société Minière du Sud Pacifique). The elected provincial leadership are seeking to create a financially viable Kanak entity in the north, working at present within the confines of French administrative arrangements and partial decolonisation. In order to discourage further violence and conflict, France is generally happy to support the Northern Province financially and logistically, although it is opposed to full independence for the whole archipelago, which is resource-rich and strategically important to it in the predominantly Anglophone South Pacific. The south of the island and the Southern Province is, by contrast, dominated by the Nouméa metro-region where the European heritage is much stronger and heavily Francophone in its political sympathies and culture.

Poum is an isolated district in the Northern Province. The northernmost point of Grande Terre is here, and Poum is over $160 \mathrm{~km}$ from the large Koniambo mine and growth-pole based around Koné, the provincial capital of the Northern Province (Figure 1). In this article, we go on to describe how it has remained marginal to the economic project of the Province, and not only because of its geographical location. The case tells us much about the uneven spatial politics of partial decolonization, which crosses scales to leave certain locations out of re-politicised economic development.

The district, which has existed since 1977 as a commune, contains a large bay, bordered by an extensive coral reef. A part of the lagoon in Poum is registered as a UNESCO World Heritage site and monitored by a 30-strong committee. ${ }^{12}$ The Poum administrative district was carved out in 1977, having previously been a part of the neighbouring district of Koumac. It had 1,388 inhabitants in 2009, 80 per cent of them identifying as Kanak, with only 2.92 inhabitants $/ \mathrm{km}^{2}{ }^{13}$ Poum's peculiarity lies in its colonial settlement history and complex relationships between inhabited small islands (Baaba, Yande, Taanlô and Yenghébane, all with less than 20 year-round inhabitants, and Tie) set in a large bay, and the mainland (see Figure 1). The villages belong to two customary districts: Arama and Nenema, part of the Hoot Ma Waap cultural region of northern Grande Terre. ${ }^{14}$ Nouméa is over 400 $\mathrm{km}$ to the south and is connected by road. There is one small European-style administrative centre in the district consisting of a school, post office, police station, church, clinic and municipal offices. There is also a public body called OGAF (Opération groupée d'aménagement foncier) that assists with local development, particularly fishing and tourism. Without a shop, convenience goods, fuel and ice for fishermen come from up to an hour's drive away. The administration is the most important employer. The second is tourism because tourists, attracted by the visual beauty of the bay and islands, can stay in the Malabou Beach hotel south on Nehoue Bay, a relatively luxurious resort owned by Grands Hôtels (a Northern Province group) with over 35 employees, in two cottages (Golone and Poingam), in a camping site (Pagop) or with local people. Cruise ships once docked regularly in the Poum lagoon and facilities for visitors are still visible, but the activity stopped in 2010 because of a customary and economic conflict described below. An important source of revenue for local residents was lost.

Fishing presents opportunities for the islanders, especially for the Kanak village of Tiabet. There are approximately twenty licensed commercial fishermen, but they cannot easily obtain bank loans for boats and equipment. They also report a declining catch over the last few years. Another problem is the lack of a cold chamber for storing their catch. Fishermen need a licence to sell directly to hotels or other official outlets and most of them cannot afford this. So the fishermen sell directly to intermediaries, who have permits to take fish to markets or supermarkets in Nouméa. The district also has a small labour force maintaining its roads and infrastructure. Other local employment is with the Poum mine, which is not at full production and currently has approximately thirty employees on the escarpment south of Titch. It is owned by the chief French mining company in New Caledonia SLN (Société Le Nickel), and there is also a substantial outflow of workers to Koniambo, Tiebaghi and other mines. Agriculture is limited because of infertile soils and water supply difficulties. 
Figure 1: District of Poum, showing areas of conflict ${ }^{15}$

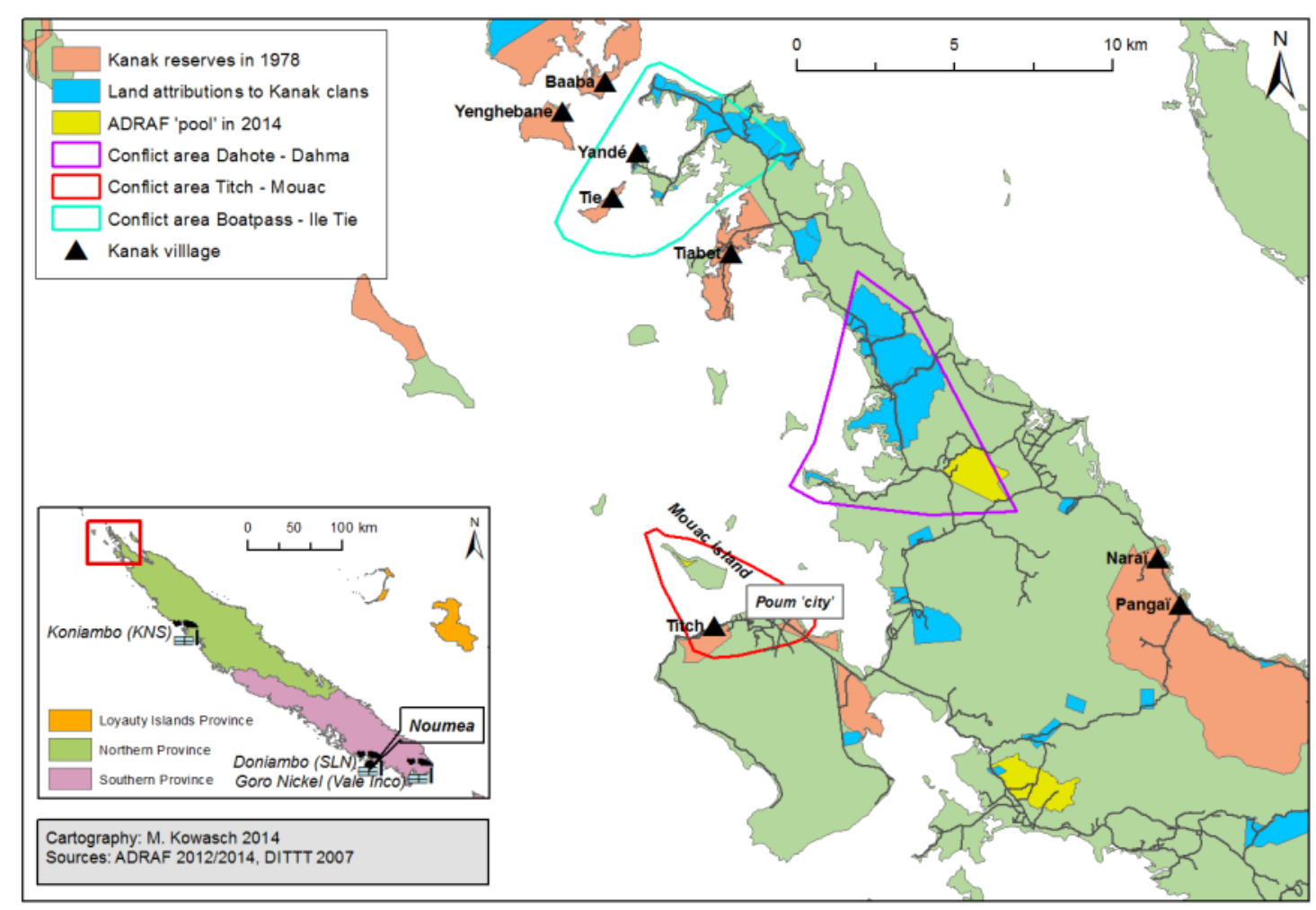

Titch is the only Kanak village on the Poum peninsula itself, with a population of $120{ }^{16}$ The inhabitants belong to four clans: Boaouva, Padi, Boula and also Tidjine. The Tidjine clan originate from a much older village on the other side of the mountains (Crescent Bay), which was abandoned with the arrival of Christianity nearly 130 years ago. At this time, the London Missionary Society was active around the bay and on the islands. The Boaouva clan offered land to the Tidjine families, according to customary practice. The Padii and the Boula clan are allies of the Boaouva: they 'walk together' in customary issues. The small European population is largely engaged in pastoralism and tourism management.

New economic activity on customary land in New Caledonia tends to spark conflicts. Traditional landowners assert their rights and attempt to claim future material benefits. In Poum, mining and tourism projects each appear to promise benefits for the traditional landowners, but local aspirations have been thwarted by deals and compacts made outside the region. In what follows, we explain the different land claims and conflicts around land and sea tenure and analyse the strategic logics of the competitive actors in Poum.

\section{Land as identity card and intellectual property}

In New Caledonia, the identities of indigenous Kanak peoples are built on the clan's history, recorded and transmitted orally; the duration of occupancy is always a source of respect and prestige. Land is a form of cultural identification for many Kanak. ${ }^{17}$ For the Kanak pro-independence leader Jean-Marie Tjibaou, murdered in 1989, 'land is not apprehended as an objective reality of property. A clan, that loses its land, loses its personality'. ${ }^{18}$ The geographer Jean-Pierre Doumenge defines land as an 'identity card, a place where the totem acts, the ancestors rest in peace, recipient of beliefs and sign of the social status [of clans]'. ${ }^{19}$

The specificity of the clan in New Caledonia is its history: the place and circumstances of its appearance, the journey that the clan undertook, and the recognition of its symbolic importance. The 
social identity of each clan is registered as an itinerary, as a series of places where the group passed. ${ }^{20}$ An identity is always constructed and never given. The places where the clan lived are deemed sacred and all have a name in one of the twenty-eight Kanak languages. Land legitimacy follows from these sacred sites. This applies to Kanak as well as to other indigenous communities. ${ }^{21}$ Land can also be given to another clan for agriculture or settlement. In this case, the transfer of land is not a transfer of property, but confers overlapping legitimacies. The original inhabitants share land rights with settlers. Lund and Sikor note: 'Obviously, legitimacy is not a fixed and finite substance: it is a result of processes of legitimization, some with distinct authorship, others as reproduction of mores; some successful, others less so' ${ }^{22}$ In this sense, land legitimacy and property are subjects of perpetual construction and renegotiation. ${ }^{23}$

During early French colonization, there was little negotiation. Many indigenous peoples were driven from productive or useful land onto reserves by the new settlers through the cantonnement policy that began in 1880. Cantonnement created a veritable wall between the two populations. ${ }^{24}$ The situation around Poum is unclear, but it seems the worst effects of cantonnement were avoided by virtue of the region's geographical marginality, and by the European heritage of some of its fisher population. Land was taken, however, for mining and ranching. Pro-Kanak land reform in New Caledonia started in earnest in 1978, with the goal of rebalancing land allocation between indigenous and allochthonous peoples. ${ }^{25}$ The main goal of the public agency ADRAF (Agency for Rural Development and Regional Planning) has been the acquisition of private land and its redistribution to Kanak clans. ADRAF buys private land with state funds, and researches different land claims before redistributing the estates. The clans form a so-called GDPL ${ }^{26}$ in order to claim land. An ADRAF 'pool' consists of acquired land, often held back from reallocation by concurrent claims or conflicts. In 2010, private land and Kanak customary land attained parity for the first time on Grande Terre at 295,300 hectares each (see Figure 2). In recent times, ADRAF has also been involved with facilitating economic development activities on customary land.

Figure 2: Land distribution over time on Grande Terre (Source: ADRAF 2012) ${ }^{27}$

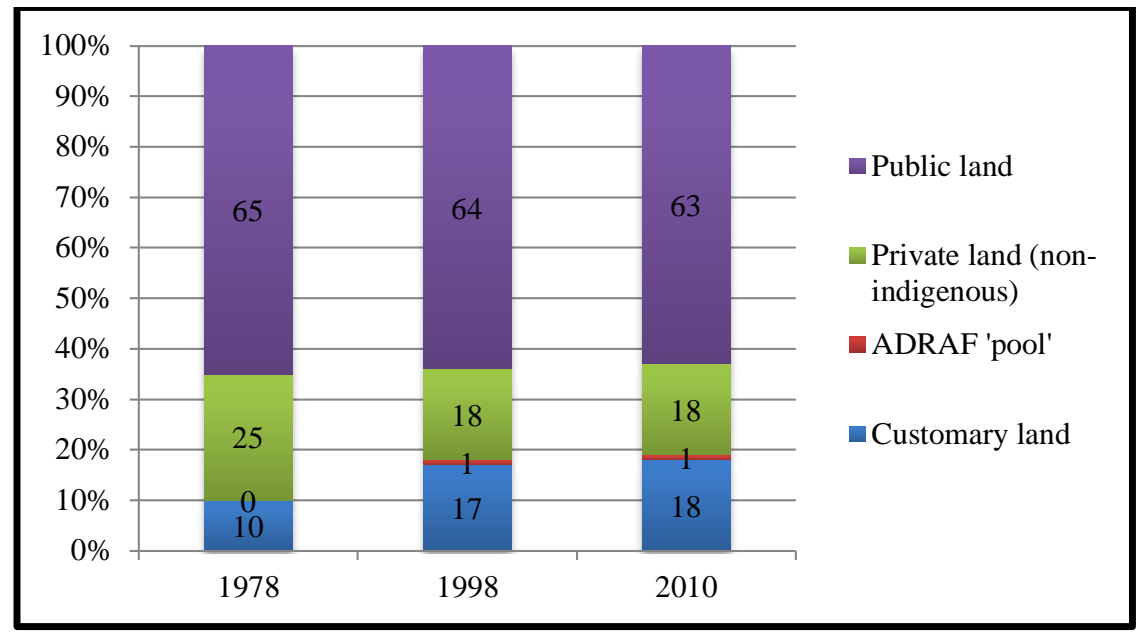

Marilyn Strathern suggests that 'land' is also a form of intellectual property. She notes that 'in Western jurisprudence land is often held up in contrast to intellectual property as the example of something that is manifestly tangible'. ${ }^{28}$ But in Melanesia, people value 'the intangible but vital capacity for relationships that the land and its fruits mobilize'. ${ }^{29}$ As Noel Castree states:

To simplify, many indigenous peoples are currently seeking to reappropriate three things that, historically, have been taken away from them: namely, parcels of land and water, material artefacts (e.g. ceremonial goods like masks), and knowledges (e.g. designs and medicinal remedies). ${ }^{30}$

In New Caledonia, two customary associations that involve several Kanak clans, one from the district of Yaté in the Southern Province, have used the 2007 United Nations Declaration on the Rights of Indigenous Peoples to make such claims. Article 28.1 of the Declaration explains that: 
...indigenous peoples have the right to redress, by means that can include restitution or, when this is not possible, just, fair and equitable compensation, for the lands, territories and resources which they have traditionally owned or otherwise occupied or used, and which have been

confiscated, taken, occupied, used or damaged without their free, prior and informed consent. ${ }^{31}$

Equitable compensation in the form of royalties to indigenous landowners signifies a source of revenues and material security, but depends on knowing who the landowners are. As Castree explains, property rights 'are among the most legally secure and materially effective rights that individuals and groups can possess. These rights promise to be an important tool for those indigenous groups seeking to exert strong forms of place control. ${ }^{32}$ In northern New Caledonia, while property rights have advanced significantly in the late $20^{\text {th }}$ Century, royalties, cash payments or other forms of compensation are not paid as a matter of policy, ostensibly to avoid conflicts between different clans who claim legitimacy.

\section{Colonial settlement, Kanak land claims and attributions in Poum}

Today, 67 per cent (31,103 hectares) of Poum's territory is in public ownership, 17 per cent $(7,874$ hectares) is designated customary land and 16 per cent (7,323 hectares) are private estates, the latter held by a range of individuals including settler families like the Winchesters who, for example, completed a major land sale in $1978 .{ }^{33}$ A catalogue of land transactions and claims indicates that from 1882-1972 there were some additions and subtractions to customary land in the Nenema district, generally administrative in nature and without major losses to private individuals. ${ }^{34} \mathrm{~A}$ distinctive feature today is the 781 hectares or 10 per cent of the acquired land still in the ADRAF 'pool', because it has ambiguous or overlapping claims. ADRAF has identified three areas of major land conflict: Titch-Mouac, Dahote-Dahma and Boatpass-Île Tie. Titch-Mouac and Dahote-Dahma are conflicts between clans, while Boatpass-Île Tie is an internal clan conflict. Given the gradual restitution of land since the 1970s, there are no major disputes between European settlers and Kanak remaining, other than issues with the SLN Poum mine.

The Titch-Mouac-conflict consists of the overlapping land claims of the Boaouva, Padii and Boula clans on the one hand and of the Dayé clan on the other. Both groups claim land on the Poum peninsula and on Mouac island, including a plot in the administrative village of Poum where a small commercial development and filling station will be completed. In 1978, the Land Office ${ }^{35}$ recorded the first land claim on the peninsula, by the Boaouva clan. In early 1980, it claimed the entire peninsula including the mine. In 1986, the first land attribution was made for the Boaouva clan; a plot with an area of 25 hectares which is located in the North-East of the peninsula. In 1992, the Boaouva, Padii and Boula clans founded a GDPL called 'Boubopa' and in 1995 they received 168 hectares. Today, the GDPL Boubopa estate covers approximately 200 hectares.

The first Dayé claims date back to 1978 and cover the islands of Mouac and Néba. Since 1980, the Dayé have also claimed the land where the administrative village of Poum is located. In 2008, they sent a letter to ADRAF also asking for customary recognition on the Poum peninsula, as they asserted first arrival privileges as traditional 'landowners'. Recently, this claim has been abandoned. No land has yet been attributed to the Dayé clan.

The Winchesters are descendants of Scottish fishermen who were drawn to the islands for the seacucumber trade and later intermarried with Kanak. Alexander Winchester arrived on Mouac around 1855 and married a Kanak from Maré. They had three children. In the 1850s, a hundred Europeans lived the region's capital of Mouac. Community life was based on fishing, agriculture and trading. ${ }^{36}$ John Henry Williams (probably of English origin) moved to neighbouring Néba island, ${ }^{37}$ but the Williams family appeared to have retained private property on Mouac. Today, some of Mouac Island is potentially subject to state attribution through ADRAF, while the other half is privately owned land bought from the Williams family by the Winchester family in 1932.

To end years of conflict over control of this small island ADRAF wants to buy the rest of the land from the Winchester family to surrender it to the Dayé clan. The Winchester descendants are no longer living on Mouac but there is still a family cemetery there. At the time of writing they will not 
sell all their land, but ADRAF has negotiated for the restoration of a small 6 hectare part to the Dayé. At the same time, the Boaouva clan have recently asserted that there is a sacred place on the island.

It was P\&O Cruises Australia, working with the local company 'Poum Adventure', that organized a cruise ship program in the bay. In 2003 a committee was created which brought together the Boaouva and Dayé clans. The committee was responsible for maintaining beach facilities on Mouac Island (Figure 3), organizing activities in the 'Shelloh village' in the administrative centre of Poum (dancing, sale of handicrafts and food) and managing finances. In Poum, some cruise passengers were taken to see Titch and the administrative village. Others visited the mine by bus. On Mouac, the passengers stayed on the beach and had a large barbecue. In 2007, four P\&O Cruises Australia ships came to New Caledonia making a total of 158 stops, 5 of which were in Poum. The committee received around 400,000 CFP (US\$4,611) for each boat arrival from the tour operators. Since the cessation of activities in 2010, the infrastructure on Mouac and in Poum has fallen into disrepair (Figure 3), although in 2013 and 2014 the Shelloh site in Poum was used for the Shaxhabign cultural festival and a seafood event. ${ }^{38}$

Figure 3: Mouac island (Source: M. Kowasch, July 2012)

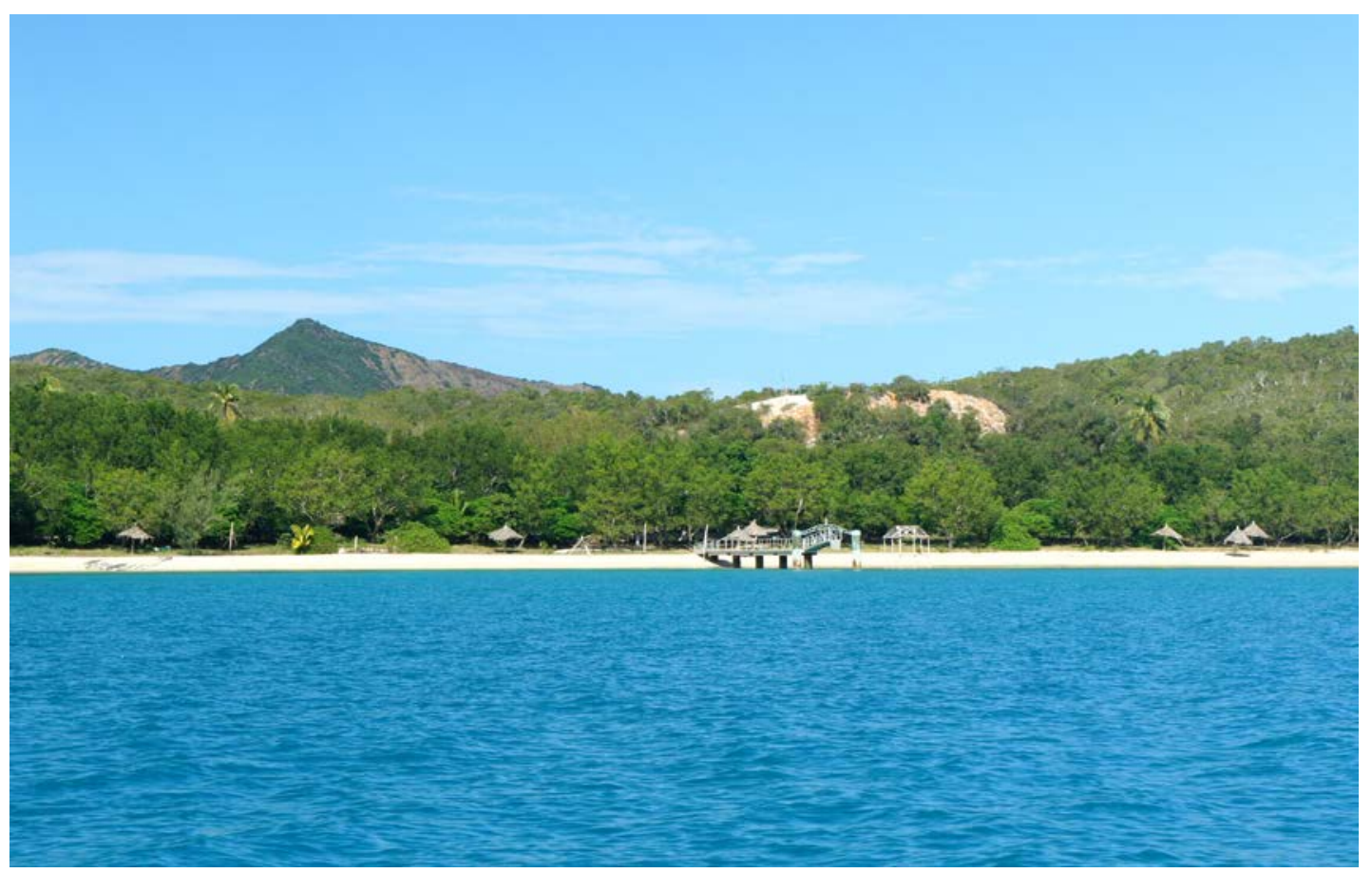

Two issues seem to have led to the withdrawal of these cruise visits. One concerned alleged misappropriation of committee funds, while the other concerned the existing land conflicts over Mouac. In any event, the women of Titch are still disappointed with the shutdown, which gave them some income. Whatever the truth of the land tenure issues, the claims to Mouac seem to conceal economic interests in the potential profits from the cruise ship visits.

\section{Mining history and development in Poum}

A second major source of conflict is the relationship between mining and local clans around Poum. Nickel, copper and other minerals have been exploited patchily since the 1870s. The first traces of mining extraction date from 1876, when a certain M. Beauvais is mentioned in the Official Journal of New Caledonia (JONC) as obtaining a cobalt concession of 300 hectares. In 1894, M. Montagnat applied for another cobalt exploration in competition to M. Beauvais and obtained 232.3 hectares in March 1895. Mines were also developed on the islands of Baaba (1904) and Yandé (1906). Other mining operators followed, including British companies using New Caledonia’s penal labour.

In 1911, the JONC notes that M. Montagnat waived his mining concessions in Poum and lost them in 1913. The first large nickel concession was begun during the Second World War. The companies 
Lafleur and Ballande carried out further small scale exploitation at the top of the Poum massif between 1954 and 1965, with negative environmental impacts: nickel deposits are located in mountaintops, and early mining simply blew up and bulldozed these sites, leaving them bare and sometimes with polluted spoil pushed over into river basins. In 1962, there was an initial conflict between the Lafleur company and the village of Titch, which wanted compensation for mining waste descending into the community and denying them clean drinking water. Finally, Lafleur made the chief of Titch a cash payment, built a new channel, and delivered 10 trucks of sand to the Kanak village. ${ }^{39}$ Between 1965 and 1970, the American Patino Mining Corporation bought the mining titles from Lafleur and Ballande. During a boom in prices, the possibility of constructing a ferronickel processing plant was discussed for the first time; the added value from nickel comes when it is smelted down, and then sold as ingots. Patino and the French SLN became partners of the French mining company COFREMMI (Compagnie française d'entreprises minières, métallurgiques et d'investissements) in order to create the mining operator SOMMENI (Société Métallurgique du Nickel). SOMMENI was charged with exploiting the Poum and also the Tiébaghi deposits further south, to begin in 1973, and to build a nickel smelter with a production capacity of 40,000 tonnes. In 1972, the potential project was displaced from Poum/Tiébaghi to Koumac around 60 kilometres south of Poum. But the different companies withdrew with the declining price of nickel on the world market. Four years later, the French state reproached Patino for not building the smelter and repurchased its Poum and Tiébaghi mining titles. In 1996, the New Caledonian SMSP took up the Poum peninsula mining titles but soon gave them up in light of the major political economic manoeuvrings occurring elsewhere on the island.

SMSP is owned by the Northern Province of New Caledonia and supported by the independence movement, so its involvement in mining is linked to the economic aspirations of Kanak people. Kanak had long felt the dominant SLN company took its profits to France, and to its parent company Eramet. The SLN was at the time the only company with a nickel processing plant in New Caledonia. ${ }^{40}$ In the 1990s, SMSP and the Northern Province began a search for an industrial partner to build their own nickel processing plant in the hopes of adding local value to ore mining and to rebalancing the disparities between the north and the south as part of political emancipation for the Kanak peoples. SMSP also wanted to break the stranglehold of having to use the antiquated Doniambo smelter and so they partnered with the Canadian group Falconbridge, at the time the third largest global producer of nickel, to develop a major project.

The problem for SMSP was that they did not control sufficient nickel ores to supply a processing plant. Such a large project would need enough nickel to be viable for 50 years. The French Prime Minister Lionel Jospin favoured a new smelter and the French government held that the best solution available was to transfer the mining titles of SLN-owned Tiébaghi massif in Northern Province (well to the South of Poum) to SMSP in exchange for the Poum titles. ${ }^{41}$ If the smelter was built on the Poum peninsula it would receive ores from both the Tiébaghi and Poum massifs.

The proposed plant, whose exact location we could not discover, would have transformed Poum into a substantial industrial centre, however Eramet/SLN and the French industrial Minister vetoed the transfer of the mining titles. In Versailles in 1997, negotiations about economic diversification in the north continued. But they were curtailed by a master-stroke. André Dang, head of SMSP, a man with Vietnamese origins but strong Kanak sympathies, proposed a new deal: instead of Tiébaghi, vest SLN's Koniambo ${ }^{42}$ titles to SMSP in exchange for the Poum mine. The French state wanted the negotiations to succeed, New Caledonia needed political stability, and the guaranteed access to nickel resources was a condition of the independence movement for continuing negotiations with the loyalists. The country had strikes at the time and there were real fears of a new civil war developing. ${ }^{43}$ After some pressure from the French government, Eramet/SLN finally accepted the swap of the mining titles with adequate financial compensation, and a clause about a re-exchange of the titles if the Koniambo plant was never built. The 'Bercy Agreement', was signed in February $1998 .{ }^{44}$ Poum was the victim of this episode of political pragmatics.

SMSP was permitted to continue mining in Poum until 2002 and then 2005 following social troubles in Titch, with due compensation to SLN for this delay. Since 2005, the transfer of mining titles has been irreversible. The hopes of the local population for a smelter in Poum, with employment and 
economic development, were extinguished. Local residents feel overlooked and marginalised by regional and global forces outside their control. With SLN now in control of the Poum deposits, the regional population at least have hopes for some expansion of the mine. SLN believes faster exploitation of the acidic nickel-rich deposits may wait until the economics are more favourable, probably not before 2019, although world price fluctuations could easily change this. But the local population is voting with their feet: newspapers ran several articles in 2013 and 2014 about outmigration of the already small population, resulting in a strong decline in school enrolments in Poum and Arama. Many families are moving south to the Voh-Koné-Pouembout zone to seek employment in and around the now-operational Koniambo project.

\section{Mining benefits and environmental damage in Poum}

A third source of discontent is the environment, driven by concerns over water quality and water management. Today, nickel production from the SLN mine is a modest 25,000 tonnes of ore per year. ${ }^{45}$ Direct material benefits from the mine are quite slight: SLN employs only 10 people on site (four administration jobs and six truck drivers). Six workers come from Poum, one from the district of Ouégoa on the East coast, the rest from elsewhere. The international literature shows many cases where material benefits from mining development are generally lacking for local indigenous peoples. ${ }^{46}$ Poum is no exception. There are not even cash payments for damage sustained to natural environments.

Environmental mining impacts are often described as a 'disaster' for local peoples. ${ }^{47}$ In Poum, the mining development has had a significant impact on drinking water. The supply to the administrative village of Poum and Titch is a constant problem. Poum has three groundwater reserves, the best and largest of which is Titch at the foot of the plateau where SLN and its predecessors extracted nickel. During periods of heavy rainfall, the water is undrinkable, polluted with mine runoff. Mining has also led to erosion and landslides. Most of the inhabitants refuse to pay for their unreliable and polluted drinking water. ${ }^{48}$ Although SLN has dug some new bores, water is consistently trucked in at great expense for the commune, and locals have blockaded the mine on several occasions for this reason and during labour disputes. These are reminiscent of other strikes and blockades against SLN caused by multiple grievances. ${ }^{49}$ SLN is proposing new bores to supply drinking water if other arguments about land access and control can be resolved. Water has become an emblem of the larger sense of disenfranchisement and loss of economic development; like access to land, access to clean water is a source of socio-political struggle, not only a health and sanitation issue.

\section{Subcontracting, local development and customary conflicts in Poum}

The lack of compensation for mining damage can be explained politically. In the Northern Province, governed by the independence party PALIKA (Parti de Libération Kanak) in cooperation with proindependence delegates, a request for royalties or cash payments to compensate for environmental damage or for the appropriation of land is not generally permitted. Politicians want to avoid rentseeking and clan conflict, and prefer instead that local populations become partners in enterprises or that the guilty party fixes the problem. The case of subcontracting in Poum, which is rather complex but important to our story, is illustrative of this debate and a fourth issue for potential conflict. Subcontracting can generate economic and social benefits for indigenous peoples, particularly where royalties are denied. ${ }^{50}$

In Poum, five companies are subcontracting for the French mining company SLN: they are SONAREP (Societe de roulage d'exploitation et de navigation de Poum), Nickel Poum, CALTRAC, VHP and GéoPoum. The subcontracting company Nickel Poum originated in the GDPL Yadashaya, which represents a part of the Boaouva clan. During heavy rainfall in 2008-09, mining waste storage crumbled and pollution scattered in the lagoon. As SLN holds the mining titles, the company was obliged to restore the damage. Nickel Poum won the sub-contract. It has 12 workers, dispersed in seven different enterprises, with a small profit margin of between 10-16 per cent. VHP, CALTRAC and GéoPoum employ all two or three people, most of them from Poum, though GéoPoum is the most 
localised. The mineworkers, thirty in total, include subcontractors. SLN wants to extend their nickel production in Poum, from 25,000 to 50,000 tonnes, but their future plans are uncertain. They prefer to create nickel ingots in New Caledonia, and then sell those, rather than exporting the ore overseas for processing, as SONAREP would prefer.

Described as the 'Engine of Poum' by the Caledonian newspaper Les Nouvelles Calédoniennes, SONAREP is the fifth subcontractor, created in 1999, and it has the explicit objective of creating local jobs. The GDPL Boubopa is the majority shareholder of the small company, with 42 per cent of the shares, while SOFINOR (Société de financement et d'investissement de la Province Nord) holds 34 per cent of the shares, and the individual shareholders 24 per cent. ${ }^{51}$ SONAREP loads nickel ore onto boats, working for companies across the island, including the SMP mining company in Poro on the East coast and at the Ngo mine in Plum in the South. They have worked in Poum since 2009. In 2011, SONAREP had 25 casual employees (ten tug boat sailors, five wharf hands and ten on cranes). The relationship between SLN and SONAREP remained tricky, with SLN offering only subcontracting and no closer contractual arrangements. SONAREP blockaded the mine for this reason, most recently in November 2013.

Because SONAREP considers itself as an economic instrument to help local communities, it distributes donations to social associations and institutions in Poum. In April 2012, for example, it dispensed US\$24,650 including $\$ 10,600$ to a Poum cricket team, $\$ 4,260$ to the Poum secondary school, $\$ 1,130$ to the boarding school, $\$ 1,060$ to the seafood association, $\$ 1,130$ to the Catholic school in Arama and a further U\$4,250 to primary schools in Poum and Tiabet (Les Nouvelles Calédoniennes, July 4, 2012). In 2011, the company gave a respectable dividend of US\$17.30 per share to its shareholders.

Fuel supply remains a major issue in Poum. The official filling station is 60 kilometres south. Without petrol, boat trips for tourists and fishing can suffer, as does some small investments in agriculture. In 2012, SONAREP began a project on land it has purchased close to the Poum wharf to construct a filling station and shop, calling this a 'commercial centre'. Customary and economic conflicts then stalled the development after the foundations were laid, with longstanding inter-clan debates stalling its completion. SONAREP was in competition with Nickel Poum to build it. The directors of SONAREP and Nickel Poum both come from Titch and are both Boaouva. The social arena is tight, with competition between actors that know each other well, and yet have different interests. Economic, customary and land legitimacy conflicts overlap. Negotiations and arrangements become complex, because personal and family relationships enter in the 'arena'. Nevertheless, in mid 2014, progress was reported: 'A grocery store, a filling station, a shop for household goods... The future shopping centre will make life easier for residents and tourists. Work is progressing and the shops should be delivered in late June' (Les Nouvelles Calédoniennes May 6, 2014).

\section{Contested places: land legitimacy without real land attribution?}

How to satisfy a request for land legitimacy by indigenous peoples, as Poum has experienced, without real land attribution through private property? ADRAF is conscious of this problem as it works through the messy politics of land tenure, but resolution is not obvious. There are two layers of claims to be distinguished: the first is a grant of land to a person or a group. The second is not land attribution, but a simple recognition of traditional land ownership, a 'right to the place'. ${ }^{52}$ Paul Néaoutyine, President of the Northern Province and a prominent pro-independence leader, sees local land claims in a national context: 'If we refer the claims to clan property, it may lead us to recognize that there are areas that are 'free'. We see things differently: we use the land claims to claim the entire New Caledonia. ${ }^{53}$ In this way, claims to the Poum peninsula are unlikely to stop its current use; SLN will not halt mining nickel because of any adverse resolution of land claims.

Contested places and land conflicts are generally first occupancy disputes, as we find all over Grande Terre. The land claim (or legitimacy claim) does not take place in a political vacuum. As Lund and Sikor note, 'Enforcing certain decisions about property is often met with resistance from those whose rights are eroded in the process. ${ }^{54}$ This same kind of conflict emerged on Mouac. In this case, 
legitimacy claims exist in parallel, and no clan rights have yet been eroded; but the actions of asserting these claims have had negative economic consequences when the cruise ship visits stopped.

The financial benefits from the cruise ship visits were managed by the Shelloh committee. The distribution of money also led to disagreements exacerbated by customary disputes. Future financial benefits from activities on the island colour a lack of resolution of the issue. A customary process may take years to resolve, even decades. It may be that both parties find an agreement, but this remains uncertain. Land claims can, after all, be a kind of instrument for receiving financial benefits. Castree notes that it is 'often the case that claims about nature - and actions based upon those claims - can serve as instruments of power and domination'. ${ }^{55}$ Indeed they do.

Nonetheless, postcolonial social arenas, land claims and property are not the only way by which indigenous peoples are able to benefit from natural resources. 'Access' can include access to employment, education and services. Ribot and Peluso explain that 'In addition to property, these include technology, capital, markets, labour, knowledge, identities and social relations. ${ }^{56}$ In the case of Poum, the local subcontractors to SLN benefit from the nickel industry, not through royalties, but via the labour market. Lund and Sikor highlight that it is not uncommon that 'people may hold property rights to some resources without having the capacity to derive any material benefit from them'. ${ }^{57}$ The authors distinguish 'property' from 'access': 'This is exactly what the distinction between property and access is about: property is about claims which are considered legitimate, and access is about the 'ability to benefit". In Poum, access to land, clean water, and to economic benefits are all pressing issues.

\section{Conclusions}

In a social arena different actors compete over economic benefits, development, legitimacy, prestige and power. A variety of 'actor strategies' are pursued by Kanak peoples to obtain material benefits for households, clan or community and in anticipation of future development. These differ markedly from Western conceptions of private property, individual advancement and management of natural resources. There are five factors that emerge from this analysis of the social arena of Poum and its location in a French settler colony with attenuated global economic links.

First, the social arena is characterized by the loss of development opportunities and lost hopes: local 'struggles for recognition and emancipation' ${ }^{58}$ The project to build a northern nickel smelter to 'rebalance' the territorial economy settled not in Poum but 160 kilometres to the south. Local peoples perceive this as a missed opportunity, even if mining extraction in Poum could have meant exacerbating negative environmental impacts such as the water pollution that some households already suffer. The geographical isolation of Poum means this issue of a loss of employment and a development opportunity is still felt keenly; it remains a dominant narrative among local people.

Second, environmental issues, like water supply and pollution, can be used as a visible and symbolic tool to bargain for larger concerns, in this case to re-establish local control of mining development. Water quality in Titch has become a symbol of alienation from economic development. Yet mining and tourism based on the attractive bay and islands will find it hard to coexist in the district, a point not lost on local political representatives. Water quality and supply are still real problems in Poum. The district administration negotiated with SLN to reduce environmental impacts and to take greater care over holding-tank failure and erosion. Indigenous subcontractors repaired damage following heavy rainfall but there was no compensation paid or permitted. The lagoon to the North of Poum is one of the six marine clusters around the islands on the World Heritage Sites List, which is potentially valuable for tourism if mining discharges can be avoided. The World Heritage status of the lagoon warns mining operators that their activities are controlled to a certain extent.

Third, we have to distinguish different perceptions of 'development' operating in this complex social arena. The main goal of the indigenous subcontractor SONAREP is to plough profits back into support for the local Melanesian population. The Kanak culture of benefit-sharing coexists with commercial activities. In contrast, the mining operator SLN is bound to global shareholder demands and market forces. Different perceptions of development can create conflict over what constitutes real 
local development - large scale resource exploitation, or small scale economic activity with funds put back into community institutions? It is unclear that SLN has really obtained a 'social licence to operate' from local residents since assuming control of the mine.

Fourth, the social arena of Poum is a 'microcosm' of conflicts, negotiations and arrangements found all over Grande Terre. ${ }^{59}$ Figure 1 shows the three areas of land conflicts according to ADRAF, and we have focussed on the Titch-Mouac conflict. All the actors within this 'micro-arena' know each other, and they are often family and members of the same clan, or inhabit the same community. If any benefits or resources are not shared equitably, more power or prestige for one competitive actor decreases the power of another. People with authority often have multiple functions: director of a subcontracting company, vice-director of the municipality, and member of the council of elders in the village. New Caledonians call this 'avoir plusieurs casquettes' ('having several caps'). These 'big men' ally customary, economic and political influence. But the balance of power and authority is fragile, and a development proposal like the filling station or a land claim, with potential prestige or economic benefit, can easily disrupt it.

Finally, fifth, we have to distinguish between property rights and land legitimacy. In postcolonial New Caledonia, ADRAF, while aiming to return private (mostly settler) land to Kanak clans, finds the attribution to legitimate claimants to be problematic. Land is an identity card for Kanak clans, whose social status is interwoven with land access and control, but often without 'real' property legitimated by the state and cadastral surveys. In this remote region property rights do not necessarily lead to material benefits anyway; the filling station was blocked for long time by conflict, and in other undisputed areas, tourism and ranching has advanced very slowly. In this way, symbolic attachment to land and property sits in an uneasy relationship with the unrealised possibilities of economic development. But visions of future development are themselves conflictual. Tourism will conflict with mining, and modern facilities conflict with aspects of heritage and custom. The social arena in this fascinating region is simultaneously social, political and economic.

\footnotetext{
${ }^{1}$ Christian Lund and Thomas Sikor, 'The Politics of Possession'. In Access and Property: A Question of Power and Authority. Ed. Christian Lund and Thomas Sikor, (Oxford: Wiley-Blackwell, 2009): 1-22.

${ }^{2}$ We thank the Institute of Research for Development (IRD) for advice and administrative organisation of fieldwork in Poum, especially Pierre-Yves Le Meur and Jean-Brice Herrenschmidt. We acknowledge funding from the Caledonian CNRT 'Gouvernance minière' research project directed by Le Meur. Finally, we are deeply thankful to everybody in Poum who responded to our questions. Special thanks to Narcisse Boaouva from Titch who welcomed and accommodated Neumann.

${ }^{3}$ Jean-Pierre Olivier de Sardan, Anthropology and Development: Understanding Contemporary Social Change. (London \& New York: Zed, 2005).

${ }^{4}$ Tate LeFevre, 'Representation, resistance and the logics of difference: indigenous culture as political resource in the settler-state'. Settler Colonial Studies, 3, no. 2 (2013):136-140.

${ }^{5}$ Kowasch, Matthias, 'Le développement de l'industrie du nickel et la transformation de la valeur de l'environnement en Nouvelle Calédonie', Journal of Political Ecology 19: (2012a) 202-220, quote on p205. online http://jpe.library.arizona.edu/Volume19/Volume_19.html

${ }^{6}$ Tate LeFevre, 'Turning niches into handles: Kanak youth, associations and the construction of an indigenous counter-public sphere'. Settler Colonial Studies, 3, no.2 (2013), 215.

${ }^{7}$ Fieldwork was conducted by the authors in November 2011 and in July 2012 in the administrative centre of Poum, on Yenghébane island and in the Kanak villages of Titch and Arama. Our qualitative enquiry consisted of over thirty informal interviews with customary chiefs and clan members, with public authorities (major and administrative staff), and as well as with subcontracting managers and the mining companies SLN and SMSP. In addition, Kowasch worked in New Caledonia before and after this study, on the perception and the participation of the indigenous Kanak peoples in the mining sector, mining governance, local development and the values attached to places. Neumann worked in Poum for several weeks in 2012 during an internship at IRD and explored the Caledonian archives. He was welcomed by a Kanak family in the village of Titch.

${ }^{8}$ Peter Brown, 'A singular plurality of voices: tradition and modernity'. In Francophone voices, ed. Kamal Salhi, (Exeter: Elm Bank Publications, 1999). Pp 125-140.

${ }^{9}$ Isabelle Merle, 'La construction d'un droit foncier colonial. De la propriété collective à la constitution des réserves en Nouvelle-Calédonie’. Enquête 7 (1998): 97-126.

${ }^{10}$ Mathias Chauchat, Les institutions en Nouvelle-Calédonie. (Nouméa: Centre de documentation pédagogique de Nouvelle-Calédonie, Collection Université, 2011). Matthias Kowasch and Peter Lindenmann.’New flags,
} 
upward forces and sheltered harbours: The new 'Great Game' in the Pacific Islands region'. Pacific Geographies $\quad 41, \quad$ Jan/Feb., $\quad$ (2014): $\quad$ 4-9. $\quad$ http://www.pacificgeographies.org/pg41/PG41_kowasch_lindenmann.pdf. Nick Maclellan, 'Politics heats up in New Caledonia'. Islands Business, February, (2013): 17-20.

${ }^{11}$ Hamid Mokaddem, L'Accord de Nouméa pour tous. Publications de l'IFMNC. (Nouméa : Institut de Formation des Maîtres de la Nouvelle-Calédonie, 2012).

${ }^{12}$ See also UNESCO, Operational guidelines for the implementation of the World Heritage Convention. WHC. 11/01. (Paris: UNESCO World Heritage Centre, 2011).

${ }^{13}$ ISEE (Institut de la Statistique et des Etudes Economique), (2009), http://www.isee.nc

${ }^{14}$ Alain Saussol, L'Héritage. Essai sur le problème foncier mélanésien en Nouvelle-Calédonie, (Paris:

Publication de la Société des Océanistes n40.,1979). There is an anthropological literature concerning Arama, which is situated one hour's drive from Poum on the east coast. Denis Monnerie, 'Représentations de la société, statuts et temporalités à Arama (Nouvelle-Calédonie)’, L’Homme, 157 (2001): 59-86.

${ }^{15}$ Shape files supplied by ADRAF (2012/2014); DITTT (2007): Data supplied to authors.

${ }^{16}$ ISEE (2009). http://www.isee.nc

${ }^{17}$ Glenn Banks, ‘Understanding 'resource’ conflicts in Papua New Guinea', Asia Pacific Viewpoint, 49 (2008):

23-34, quote on p25; Matthias Kowasch, 'Le développement de l'industrie du nickel' (2012), quote on p203.

${ }^{18}$ Jean-Marie Tjibaou and Philippe Missotte, Kanaké, Mélanésien de Nouvelle-Calédonie, (Papeete, Editions du Pacifique, 1976), quote on p60.

${ }^{19}$ Jean-Pierre Doumenge, Du terroir ... à la ville, les Mélanésiens et leurs espaces en Nouvelle-Calédonie, coll. Travaux et documents de géographie tropicale, (Bordeaux : CEGET/CNRS, 1982), quote on p229.

${ }^{20}$ Matthias Kowasch, 'Le développement de l'industrie du nickel' (2012); Matthias Kowasch, 'Les lieux toponymiques en Nouvelle-Calédonie - un champ de recherche ouvert’. Enquêtes Rurales N¹4 (2012); Michel Naepels, ' Réforme foncière et propriété dans la région de Houaïlou (Nouvelle-Calédonie)’. Etudes rurales Janvier-juin (2006): 43-54.

${ }^{21}$ Manuel Castells, The power of identity. Oxford: Blackwell (1997).

${ }^{22}$ Christian Lund and Thomas Sikor, 'The Politics of Possession'. quote on p6.

${ }^{23}$ Matthias Kowasch, 'Le développement de l'industrie du nickel'(2012); Pierre-Yves Le Meur, 'Réflexions sur un oxymore - Le débat du « cadastre coutumier » en Nouvelle-Calédonie'. In La Nouvelle-Calédonie, vers un destin commun? ed. Elas Faugère and Isabelle Merle, (Paris: Editions Karthala, 2010). Pp 101-127; Christian Lund and Thomas Sikor, 'The Politics of Possession'.

${ }^{24}$ Tate LeFevre, 'Turning niches into handles'.

${ }^{25}$ Matthias Kowasch, 'Le développement de l'industrie du nickel', 206.

${ }^{26}$ GDPL is a local association licensed to do business, rather like an aboriginal corporation in Australia.

${ }^{27}$ ADRAF, Bilan chiffré de la réforme foncière 1978-2010 (2012), http://www.adraf.nc/images/stories/pdf/bilan_reforme_2010.pdf

${ }_{28}$ Marilyn Strathern, 'Land: Intangible or Tangible Property?’ In Land Rights. The Oxford Amnesty Lectures 2005. ed. Chesters, T., (Oxford: Oxford University Press, 2009) 13-38, quote on p19.

${ }^{29}$ Marilyn Strathern, 'Land: Intangible or Tangible Property?', 29; see also Matthias Kowasch, 'Fieldwork in a context of decolonization: the example of a French overseas territory (New Caledonia)', Erdkunde, (in press).

${ }^{30}$ Noel Castree, 'Differential geographies: place, indigenous rights and 'local' resources'. Political Geography 23 (2004), 151

${ }^{31}$ United Nations, Declaration on the Rights of Indigenous Peoples (2008): quote on p10, http://www.un.org/esa/socdev/unpfii/documents/DRIPS_en.pdf

32 Noel Castree, 'Differential geographies', 160.

${ }^{33}$ Unpublished ORSTOM land survey 1980.

${ }^{34}$ Unpublished ORSTOM land survey 1980.

${ }^{35}$ The ADRAF was called 'Land Office' until 1986.

36 The Morgan brothers arrived in 1880, and worked on Baaba, Yenghébane, and Taanlô. They exported copra. The French Ballande family were also on Baaba. Little is known about how land tenure was managed with customary owners, but clearly the settlers had the support of the territorial administration.

${ }^{37}$ Les Nouvelles Calédoniennes, 21 January 2012.

38 http://shaxhabign1.e-monsite.com/\#

39 Document 37W69 Poum Lafleur, fonds SLN. Archives territoriales de la Nouvelle Calédonie.

${ }^{40}$ This plant, called 'Doniambo’ was built in 1910 near the New Caledonian capital Nouméa, in the Southern Province.

${ }^{41}$ Leah S. Horowitz. Stranger in One's Own Home: A micropolitical analysis of the engagements of Kanak villagers with a multinational mining project in New Caledonia, PhD thesis, Australian National University (2003); Matthias Kowasch, Les populations kanak face au développement de l'industrie du nickel en Nouvelle- 
Calédonie, Thèse de Doctorat de Géographie, Université Montpellier III/ Université de Heidelberg (2011) http://www.ub.uni-heidelberg.de/archiv/12305; Anne Pitoiset and Claudine Wéry, Mystère Dang, (Nouméa, Le Rayon Vert, 2008)

${ }^{42}$ Koniambo massif is located in the Northern Province, in the districts of Voh and Koné, on the West coast and in the south of Koumac.

${ }^{43}$ Pitoiset and Wéry.

${ }^{44}$ Yonanico Grenon with the collaboration of Martin Simard, 'Un projet métallurgique dans la province Nord: Koniambo'. In: Atlas de la Nouvelle-Calédonie, eds. Jean Bonvallot and Jean-Christophe Gay, (Montpellier: IRD Editions, 2012), 177; Pierre-Yves Le Meur, 'Conflict and agreement. The politics of nickel in Thio, New Caledonia'. Presented at the conference 'Mining and Mining policy in the Pacific: history, challenges and perspectives', Nouméa, 21-25 November 2011.

${ }^{45}$ Interview with M. Kadar, SLN, 27 February 2012.

${ }^{46}$ Anthony Bebbington, Social Conflict, Economic Development and Extractive Industry: Evidence from South America. (editor). (London, Routledge, 2012); Glenn Banks, 'Linking resources and conflict the Melanesian way', Pacific Economic Bulletin, 20, No.1 (2005): 185-191; Gavin Bridge, 'Contested terrain: mining and the environment'. Annual Review of Environment and Resources 29 (2004): 205-259; Colin Filer et al, 'The fragmentation of responsibilities in the Melanesian mining sector'. In Earth Matters: Indigenous Peoples, the Extractive Industries and Corporate Social Responsibility, eds. C. O'Faircheallaigh and S. Ali (London: Greenleaf Publishing 2008) pp163-179; Colin Filer and Benedict Young Imbun, 'A Short History of Mineral Development Policies in Papua New Guinea, 1972-2002'. In Policy Making and Implementation: Studies from Papua New Guinea, ed. R.J. May, (Canberra: ANU E Press, 2009): 75-116; Lee Godden, Marcia L. Langton, Odette Mazel and Michael Tehan, 'Accommdating Interests in Resource Extraction: Indigenous Peoples, Local Communities and the Role of Law in Economic and Social Sustainability', Journal of Energy \& Natural Resources Law (2008): 26:1 ; Marcia L. Langton and Judy Longbottom (eds.), Community Futures, Legal Architecture Foundations for Indigenous Peoples in the Global Mining Boom (London, Routledge, 2012),

${ }^{47}$ Tony Crook, 'If you don't believe our story, at least give us half of the money: Claiming Ownership of the Ok Tedi Mine, PNG'. Le Journal de la Société des Océeanistes (2007): 221-228 ; Colin Filer et al, 'The

fragmentation of responsibilities in the Melanesian mining sector'.

${ }^{48}$ Interview with J.P. Tidjine, chief of the customary district of Nenema, July 2012.

${ }^{49}$ Pierre-Yves Le Meur, 'Locality, Mobility and Governmentality in Colonial/Postcolonial New Caledonia: The case of the Kouare tribe (xûâ Xârâgwii), Thio (Cöö)'. Oceania 83, 2 (2013): 130-146.

${ }^{50}$ In New Caledonia, a research project funded by the National Centre for Technological Research (CNRT)

'Nickel and its environment' deals with subcontracting and its social involvement in indigenous communities

(Le Meur, Grochain and Kowasch, 2012).

${ }^{51}$ The majority shareholder is the Northern Province. Their interest in SOFINOR is to promote economic development in different sectors (mainly mining, aquaculture, tourism and real estate investment).

${ }^{52}$ See Matthias Kowasch, 'Le développement de l'industrie du nickel' (2012).

${ }^{53}$ Paul Néaoutyine, L'indépendance au présent - identité kanak et destin commun, (Paris, Éditions Syllepse, 2006), 139.

${ }^{54}$ Christian Lund and Thomas Sikor, 'The Politics of Possession', 13.

${ }^{55}$ Noel Castree, 'Socializing nature: theory, practice, and politics'. In Social nature: theory, practice, and politics. eds. Noel Castree and Bruce Braun (Oxford: Blackwell, 2001): Pp 1-21, quote on p9.

${ }^{56}$ Jesse Ribot and Nancy Peluso, 'A Theory of Access', Rural Society 68, no. 2 (2003): 153-181, quote on p159160.

${ }^{57}$ Christian Lund and Thomas Sikor, 'The Politics of Possession', 5.

${ }^{58}$ Pierre-Yves Le Meur, 'Locality, Mobility and Governmentality', 130.

${ }^{59}$ Pierre-Yves Le Meur, 'Locality, Mobility and Governmentality'. 